\title{
Sistem Daring Pembelajaran Jarak Jauh sebagai Realisasi Merdeka Belajar di Masa Pandemi
}

\author{
Aliet Noorhayati Sutisno, Dewi Nurdiyanti \\ Universitas Muhammadiyah Cirebon \\ aliet.noorhayati@umc.ac.id
}

\section{Sejarah Artikel}

diterima 28 Oktober 2020

\begin{abstract}
This cualitative research with tecnik survey is a measurement measure to obtain information about PGSD University Online Muhammadiyah Cirebon lecturers' online resilience in a covid-19 pandemic situation. The study was conducted using a survey method, the data obtained were analyzed and described qualitatively. The sample in this study amounted to 5 lecturers. The instrument used was a questionnaire that aims to capture PGSD lecturers' online resilience data. The results showed that all research samples had good online endurance with indicators covering 3 aspects of a lecturer's online endurance standard, namely: the continuity of learning in $85 \%$ of its obligations in KBM face to face, diversity of learning as an interpretation of virtual classroom management skills and the enjoyment aspect becomes the actual standard to cover the demands of changing learning patterns in the midst of a pandemic situation as it is today. The results of this survey show that learning which is the epistemology of humans in accommodating their growth and development able done the academic community in the PGSD-UMC environment even in the midst of a pandemic situation as it is now as a realization of free learning.
\end{abstract}

\begin{abstract}
Abstrak
Penelitian kualitiatif dengan teknik survey ini merupakan tindakan pengukuran untuk memperoleh informasi tentang ketahanan daring dosen PGSD Universitas Muhammadiyah Cirebon dalam situasi pandemi covid-19. Penelitian dilakukan menggunakan metode kualitatif, data yang diperoleh dianalisis dan dideskripsikan. Sample dalam penelitian ini berjumlah 5 dosen. Instrumen yang digunakan adalah angket yang bertujuan untuk menjaring data ketahanan daring dosen PGSD. Seluruh sampel penelitian menunjukkan ketahanan daring yang baik dengan indicator meliputi 3 aspek standar ketahanan daring seorang dosen, yakni: keberlangsungan pembelajaran di $85 \%$ kewajibannya dalam kegiatan belajra mengajar (KBM) tatap muka, keragaman/variasi pembelajaran sebagai representasi keterampilan mengelola kelas virtual dan aspek enjoyment menjadi standar actual mengcover tuntutan perubahan pola pembelajaran di tengah situasi pandemic seperti sekarang ini. Data ini menunjukkan bahwa pembelajaran yang merupakan epistemology manusia dalam mewadahi tumbuh dan mengembangkan dirinya, mampu dijalankan pihak civitas akademik di lingkungan Program Study Pendidikan Guru Sekolah Dasar Universitas Muhammadiyah Cirebon meski di tengah situasi pandemi seperti sekarang ini sebagai realisasi merdeka belajar.
\end{abstract}

Kata kunci: Pembelajaran daring, pandemi, merdeka belajar 


\section{PENDAHULUAN}

Kapasitas perguruan tinggi diantaranya meliputi sumber daya pendidik yang memadai dan berkualitas. (Kemdikbud, 2020). Kualitas yang memadai dari sumber daya pendidik berbanding lurus dengan pelayanan dan pemenuhan kebutuhan ilmu pengetahuan bagi peserta didiknya di tengah situasi pandemik seperti sekarang ini.

Berkaitan dengan kenyataan ini bagaimanapun pembelajaran daring bagi pendidikan di Indonesia dalam 4 bulan ini menjadi satu-satunya alternatif yang paling bisa kita tempuh dalam merealisasikan pembelajaran sebagaimana mestinya. Mengingat menghentikan kegiatan pembelajaran hingga waktu yang tidak bisa kita pastikan juga bukan merupakan solusi. Inilah tantangan bagi seluruh masyarakat dunia, tak terkecuali pendidikan di Indonesia. (Sasngko Febiarso: 2020)

Kenyataan pandemi ini sekurangkurangnya menunjukkan peluang bagi eksekusi era industri 4.0, era teknologi cyber, dimana kesemuanya serba harus berbasis internet of thing (IOT), otomatisasi dalam pertukaran data, hingga cara cerdas dalam menghubungkan manusia dengan berbagai kehidupannya. Situasi pandemic saat ini tidak lagi menuntut kita bertumpu dan mengandalkan tenaga manusia. Interaksi live, material fisikal, dengan cara-cara manual, jarak tempuh fisik yang melulu harus selalui terjangkau dengan interval waktu yang tidak bisa dikatakan fleksible. Sistem pendidikan seolah dipertemukan dengan muara surgawinya, terlebih bagi interaksi yang bersifat keilmuan, berkenaan langsung dengan daya jangkau kemampuan manusia dalam mengaktualisasikan dirinya. (Mas'udi W, dkk. 2020)

Bukan pendidikan jika tidak mampu membawa perubahan, dengan kata lain sistem pendidikan dikehendaki tidak lain untuk menciptakan angin segar perubahan manusia kepada arah yang lebih menjamin kepemimpinan hidupnya, menghadapi permasalahannya, memenuhi dorongannya terkhusus kemampuan manusia menginovasi ragam kendala yang riil menghambat kemajuannya baik serius maupun tidak untuk memerdekakan dirinya dalam belajar.

Teknologi yang dahulu dikenal dengan dua sisi mata pisau yang tajam, agaknya kini kian terkikis. Hampir selama masa pandemi covid19 manusia di seluruh belahan bumi manapun menjalankan kehidupannya mendadak harus berpangku tangan pada sistem komputasi, sistem digital berbasis iot. Disadari ataupun tidak kondisi ini mendorong manusia untuk memerdekakan dirinya dalam belajar, yang sekaligus menyatakan dukungannya kepada pemanfaatan internet dalam batas yang pantas dimaklumi sebagai multi media informasi. Baik anak-anak, dewasa maupun oarng tua, baik mereka kalangan profesi, pelajar maupun masyarakat umum. Penggunaan mereka terhadap gawai, smartphone, gadget menjadi sepanjang waktu dan tidak lagi hanya sekedar main-main, hanya sekedar aksesoris dengan sedikit manfaat positif, atau bahkan akses video porno yang belakangan sempat menjadi aspek yang sangat dikhawatirkan bagai pengguna di kalangan-anak sekolah. Dengan begitu penggunaan gawai untuk arah 
yang negatif, kini kian pudar. Gawai bisa diterima lebih ramah dan lebih dekat dalam meghubungkan manusia dengan berbagai urusan kehidupannya. ( Karim, AB. 2020)

Hal ini harus kita sepakati bersama menjadi sisi positif dari bencana pandemi covid-19 sekaligus titik terang kemajuan pendidikan. Termasuk saya salah satunya. Memanfaatkan betul masa pandemi covid-19 sebagai momen eksekusi era industri 4.0 dimana kita selaku pemangku ilmu pengetahuan dituntut untuk tetap stay at home, namun jangkauan kemampuan meraih target kerjaan masih tetap sebagaimana biasanya dengan rasio tekanan pekerjaan yang hanya berkurang sedikitnya $0,5 \%$ saja. Artinya bahwa masa pandemi masih meminta peran kita tetap berjalan normal dengan target-target kerjaan yang tetap tidak ber-tolelir. Situasi pandemi keadaan kita tidak dibenarkan untuk berpindah, berkumpul, mengadakan pertemuan atau apapun dengan tujuan pembatasan penyebaran pandemi covid-19. Efektifitas sistem dalam membantu kita merealisasikan itu semua adalah dengan bergantung penuh pada sistem iot.

Berkenaan dengan itu maka peneliti merasa perlu kiranya mensurvei ketahanan daring dosen di lingkungan Fakultas Keguruan dan Ilmu Pendidikan Program Dtudy Pendidikan Guru Sekolah Dasar Universitas Muhammadiyah Cirebon sebagai upaya realisasi merdeka belajar di masa pendemi.

\section{METODE}

Penelitian ini jenis penelitian kualitatif, dilaksankaan pada salah satu LPTK di Jawa Barat dengan melibatkan 5 orang dosen PGSD dan 20 orang mahasiswa sebagai subjek penelitian ini. Pada objek penelitian pada aspek ketahanan daring dosen selama masa pandemic sebagai realisasi merdeka belajar. Teknik dan pengumpulan data pada penelitian ini menggunakan metode survei yang hasilnya kemudian dianalisis secara kualitatif. Instrumen yang digunakan adalah angket untuk menjaring data terkait ketahanan daring dosen.

\section{PEMBAHASAN}

Mengacu kepada karakteristik pembelajaran daring menurut Koe $\mathrm{Yu}$ Tung bahwa pembelajaran daring dapat dikemas dalam bentuk teks, grafik, video, gambar maupun komponen multimedia lainnya; Interaksi pembelajaran daring juga dapat terjadi secara serentak maupun tidak; Sarana yang digunakan juga bisa beragam, dari mulai video converence, chat room, discussion room; Waktu kegiatan pembelajaran daring fleksible, peluang waktu tersedia hingga 24jam; Akses sumber belajar leluasa; Kesempatan diskusi terbuka secara formal maupun informal. (Sasongko Febiarso: 2020). Sebagaimana Hindun Khozanah dalam penelitiannya "Efektifitas Pengelolaan Pembelajaran Myob Accounting Berbasis Weblog di SMKN I Sragen", menegaskan temuannya bahwa pemanfaatan daring atau classroom virtual memberi pembaharuan dalam proses pembelejaran di kelas maupun di rumah yang dapat digunakan sebagai proses belajar mandiri (self directed learning) peserta didik . Kemudian Hartono juga dalam penelitiannya 
"Efektifitas weblog dan facebook Terintegrasi Untuk Pembelajaran Virtual" mengembangkan temuan beberapa peneliti sebelumnya bahwa pembelajaran dengan memanfaatkan media elektronik dalam penyajiannya lebih mendorong mahasiswa dalam berfikir terstruktur. Hal ini cukup menggarisbwahi bahwa enjoyment mahasiswa dalam daring tidak menutup ruang ketahanan daring seorang dosen.

Aspek ini yang kemudian peneliti jadikan pengukur standar ketahanan daring bagi sumber daya pendidik di lingkungan PGSD-UMC. Mengacu kepada ketiga temuan penelitian di atas sedikitnya meliputi 3 aspek standar ketahanan daring seorang dosen, yakni: keberlangsungan pembelajaran di $85 \%$ kewajibannya dalam KBM tatap muka, keragaman/variasi pembelajran sebagai representasi keterampilan mengelola kelas virtual dan aspek enjoyment menjadi standar aktual mengcover tuntutan perubahan pola pembelajaran di tengah situasi pandemi seperti sekarang ini.

Semakin dinamis maka semakin hidup. Begitupun dengan kegiatan pembelajaran. Sebagai epistemology pendidikan, pembelajaran idealnya mewadahi manusia dalam tumbuh dan kembangnya. Pendidikan dituntut mampu memberi warna yang cenderung terus menyempurnakan setiap usaha manusia dalam menyelesaikan tantangannya ke depan terhadap sekitarnya, baik terdekat maupun yang terjauh. (Sutisno, 2014). Pendidikan dalam proses pembelajarannya menghendaki berbagai kegiatan pencarian, pengujian dan lebih lanjut penyajian untuk lebih meningkatkan kompetensi. Dan lingkungan menyediakan kesempatan untuk berlangsungnya semua itu. Karenanya lingkungan menjadi syarat mutlak bagi terjadinya ruang hidup berlangsungnya pendidikan. Kegiatan Belajar Mengajar (KBM) dalam pelaksanaannya dituntut maksimal menggunakan ragam pendekatan semata-mata menumbuhkan potensi peserta didik pada satu atau beberapa kemampuannya (Sutisno, 2016), inilah peran dosen selaku pendidik akademik bagi para mahaisiswanya.

Daring sendiri merupakan akronim dua kata yakni dalam jaringan. Dengan pengertian sebuah sistem yang menghubungkan dua atau lebih perangkat komputer secara elektronik. Adapun jangkauan sasaran dari daring ini adalah: (1) Sebagai sharing resource (2) Media komunikasi multimedia yang efisien Manajemen sumber daya yang efektif (4) Sistem penyampaian pesan yang terpadu (5) Hak akses yang lebih fleksible, dan (6) Sistem informasi dengan tingkat kehandalan yang lebih terjamin. Sehingga pembelajaran secara daring sendiri merupakan kegiatan belajar mengajar baik antara guru dan siswa maupun dosen dan mahasiswa yang dilaksanakan secara virtual, tanpa harus bertatap muka secara langsung (Hakiman, 2020).

Daring merealisasikan pembelajaran dengan jangkauan jarak jauh, memberi peluang akses bagi siapapun secara fleksible tanpa mengabaikan tingkat kehandalannya. Artinya bahwa daring cukup kompetitif bagi ketersediaan ruang dan waktu para penggunanya. Di tengah situasi pandemi seperti ini daring untuk terselenggaranya pembelajaran jarak jauh dinilai mengcover kebutuhan arah pelaksanaan program pendidikan (Makarim, 2020).

Berdasarkan hasil angket yang disebar ke dosen dan mahasiswa 
tentang ketahanan daring dosen sebagaimana yang disajikan pada PGSD, maka diperoleh data tabel 1.

Tabel 1. Hasil Temuan Melalui Angket

\begin{tabular}{|c|c|}
\hline Indikator & Deskripsi temuan \\
\hline $\begin{array}{l}\text { Keberlangsung } \\
\text { an }\end{array}$ & $\begin{array}{l}\text { 1. Pelaksanaan KBM kelima dosen sebagai sampel tetap } \\
\text { berlangsung dari pertemuan pertama hingga data ini } \\
\text { diturunkan pekan ke } 12 \text {. Data yang berdasarkan keterangan } \\
\text { dosen terkait, keterangan mahasiswa serta dokumen laporan } \\
\text { dr KA-TU. } \\
\text { 2. Pelaksanaan KBM kelima dosen ditunjang dengan interval } \\
\text { waktu memadai } 3 \times 24 \text { jam, dengan asumsi realisasi fleksibilitas } \\
\text { hak akses materi. Keleluasaan sebagai aktualisasi realisasi } \\
\text { kemerdekaan dalam belajar. } \\
\text { 3. Tidak ditemukan kendala dalam keberlangsungan KBM secara } \\
\text { berarti, baik dari segi permasalahan teknik penyampaian } \\
\text { maupun prinsip konten materi terkait. }\end{array}$ \\
\hline $\begin{array}{l}\text { Keragaman } \\
\text { media belajar }\end{array}$ & $\begin{array}{l}\text { 1. Kelima dosen menunjukkan keragaman penyampaian materi,. } \\
\text { hal ini menjadi daya dukung tersendiri dari sebuah perkuliahan } \\
\text { daring. } \\
\text { 2. Kelima dosen menggunakan keragaman teknik dalam hampir } \\
\text { setiap acara perkuliahan. KMB dari kelima sampel terbilang } \\
\text { kreatif } \\
\text { 3. } 20 \text { mahasiswa memberi keteranagn bahwa kelima dosen } \\
\text { tersebut melaksanakan perkuliahan tidak sebatas penugasan } \\
\text { saja. Melalui keragaman media belajar (moodle, edmodo, } \\
\text { youtube, blog, dan video buatan dosen) tentu menginisiasi } \\
\text { mahasiwa dalam memperkaya sumber belajar mereka. } \\
\text { 4. Media pembelajaran yang beragam memberi akses kepada } \\
\text { teknik pembelajaran yang beragam juga. Sehingga keterangan } \\
\text { dari para mahasiswa menunjukkan kemampuan dan } \\
\text { ketahanan para dosen dalam pemanfaatan situasi pandemi } \\
\text { sebagai kesempatan adaptasi belajar daring. }\end{array}$ \\
\hline Enjoyment & $\begin{array}{l}\text { 1. Situasi pembelajaran di tengah pandemi tentu merupakan } \\
\text { sesuatu yang baru, namun kelima sample justru menunjukkan } \\
\text { kendala menjadi kesempatan realisasi merdeka belajar } \\
\text { 2. Kelima sample menunjukkan keterangan bahwa daring jauh } \\
\text { lebih efisien dalam cost dan efektif dalam waktu. } \\
\text { 3. Kelima sample menunjukkan reaksi yang enjoy. Sebagai data } \\
\text { penunjuang keterangan yang peneliti himpun dari ke } 20 \\
\text { mahasiswa kelima sample, hasilnya mahaiswa menunjukkan } \\
\text { bahwa pembelajaran daring jauh lebih menyenangkan dari } \\
\text { pada luring, dengan alasan keterbatasan kesempatan tatap } \\
\text { waktu mendorong mereka untuk lebih bersungguh-sungguh. } \\
\text { Disamping hal ini ditunjang pula oleh ragamnya penyajian } \\
\text { materi kelima dosen jelas menjadi daya dukung mereka dalam } \\
\text { realisasi merdeka belajar. }\end{array}$ \\
\hline
\end{tabular}

Berdasarkan hasil temuan dosen dapat dikatakan baik karena sebagaimana pada Tabel 1 indikator-indikator ketahanan daring menunjukkan bahwa ketahanan dari yang mengacu kepada ketiga 
penelitian sebelumnya menunjukkan respon positif pada tiga aspek penting standar mengukur ketahanan daring seorang dosen, yakni terkait keberlangsungan pembelajaran di $85 \%$ kewajibannya dalam KBM tatap muka, keragaman/variasi pembelajran sebagai representasi dari keterampilan dosen selaku sumber daya pendidik dalam mengelola kelas virtual sekaligus penyampaian materi, dan ketiga aspek enjoyment menjadi standar aktual mengcover tuntutan perubahan pola pembelajaran di tengah situasi pandemi seperti sekarang ini.

Ketahanan daring bagi dosen sangat diperlukan di massa Covid-19 ini, karena pembelajaran jarak jauh secara daring tidak telepas dari peran tenaga pendidik. Ketahanan daring seorang pendidik dalam memberi materi maupun tugas jelas memberi dampak pada pembelajaran yang membuka peluang lebih besar kepada life skill peserta didiknya. Mekanisme daring dalam pembelajaran jarak jauh selebihnya memberi peluang seluasluasnya bagi peserta didik dalam merdeka belajar. Merdeka belajar di sini maksudnya adalah keleluasaan ruang dan waktu menjadi daya dukung pembelajar dalam merealisasikan kreatifitas serta keterampilan berfikir terstruktur mereka. Hal ini disebabkan faktor karakteristik yang melakat pada pembelajaran daring yakni interval waktu. fleksibelitas peserta didik dalam menggunakan hak aksesnya menjadi nilai tambah daring dalam merealisasikan enjoyment learning. Dengan begitu daring memberi efek pada substansi belajar itu sendiri, belajar lebih terasa merdeka.

Salah satu program kerja Menteri Pendidikan di tahun 2019 terkait penyelengaraan evaluasi akhir belajar pada satuan pendidikan dari tingkat dasar hingga menengah atas memang akan mengalami perubahan. Mekanisme UN sebagai program evaluasi belajar sekolah yang selama ini terlaksana dinilai kurang efektif di tengah situasi wabah pandemi Covid19 ini, pergantian mekanisme program evaluasi tersebut seolah tereksekusi di tahun ini. Kondisi pandemi meminta masing-maisng kita harus tetap berdiam diri di rumah, serta larangan keras pada berbagai kegiatan dengan menuntut berkumpulnya manusia. Program bapak menteri pendidikan ini seolah menemui moment nya.

Wabah pandemi Covid-19 yang melanda hampir seluruh negara di seluruh dunia, termasuk di Indonesia dimulai pada bulan Maret 2020. Hampir seluruh satuan pendidikan tingkat dasar pada pengamatan awal di bulan maret terhenti, mengalami kendala praktik kegiatan belajar mengajar secara luring. Harus menjalani libur untuk kurun waktu 14 hari dimana peserta didik tanpa tugas yang harus dikerjakan selama berada di rumah, terlepas ada atau tidaknya rencana teknik ke depan dari pihak penyelenggara pendidikan dalam menyiasati kondisi pandemi ini. Baru kemudian menyusul kebijakan selanjutnya untuk kembali belajar dari rumah hingga 14 hari ke depan. Berjalannya waktu hingga terhitung 4 bulan di beberapa surat kabar maupun media elektronik sebagaoimana data yang kami himpun menunjukkan tingkat keseriusan sebaran virus di masing-masing daerah. $\mathrm{Hal}$ ini menyusul awak penyelenggara pendidikan untuk memutar haluan serta mendisain projek-projek serta program pendidikan ke depan yang baharu, sesuai tuntutan dan keadaan kondisi. Sehingga dapat di katakan bulan April menjadi timing dimana setiap pihak memulai anjuran 
pembelajaran secara daring menjadi pilihan paling dekat sebagai usaha tetep terselenggaranya target-target program pendidikan.

Jika dihubungkan dengan kebijakan merdeka belajar oleh bapak menteri pendidikan dan kebudayaan RI Nadiem Makarim di akhir tahun 2019 serta rencana menghapus program UN sebagai mekanisme evaluasi akhir belajar peserta didik pada jenjang satuan pendidikan yang dirasa kurang efektif dan efisien, tahun 2020 program pendidikan tersebut teralisasi pada kondisi pandemi seperti sekarang ini. Dengan begitu daring diperkirakan ke depan tentunya menjadi kegiatan kita bersama di segala sektor. Pembelajaran jarak jauh diprediksi akan menjadi permanen. Sehingga pemanfaatan teknologi dalam kegiatan belajar mengajar akan menjadi hal mendasar. Kesempatan situasi pandemi sama artinya menjadi kesempatan adaptasi yang bisa jadi tidak akan kembali lagi. Karena bagaimanapun ke depan situasinya lebih banyak diluar dugaan dan ekspetasi manusia.

Melihat

karakteristik

sebagaimana temuan para peneliti sebelumnya menguatkan asumsi standar ketahanan daring seorang sumber daya pendidik dapat diukur sejauh mana upaya pemenuhan pembelajaran daringnya terasa efektif menumbuhkan kebermaknaan secara personal bagi mahasiswanya. Hal ini ditunjukkan oleh hasil angket yang kami sebar kepada mahasiswa sebagai penguat data sampel kelima dosen bahwa pembelajaran daring terasa lebih menyenangkan bagi mereka. Sehingga dengan data ini dapat dikatakan bahwa efek menyenangkan dari mekanisme daring lebih kepada perwujudan kebermanaan mereka dalam belajar secara personal.

Berkenaan dengan hal ini, pembelajaran daring dalam pengamatan selama pandemi Covid19 tidak mengabaikan ruang pemahaman mahasiswa, artinya bahwa pada setiap materi-materi inti (titik fokus), para sumber daya pendidik dipastikan memiliki kompetensi dalam mendisain penyampaian materi dengan melibatkan lebih banyak ragam penyajian: seperti video pembelajaran, dengan menyertakan youtube, film pendek, pemanfaatan ragam fitur LMS, proyek pembelajaran, quiz hingga tautan materi dari berbagai sumber lain yang tentu berdaya dukung memantapan baik materi peserta didik dan kemampuan life skill lainnya. Pada beberapa temuan hasil sebaran angket yang dianalisis menunjukkan bahwa pemahaman mahasiswa akan sampai kepada substansi daring memberi bekal kemutahiran serta kelengkapan sumber belajar mereka berbasis digital. Hal ini merupakan cakupan kompetensi peserta didik dalam pendidikan yang kompetitip, sematamata menyongsong era industri 4.0. Situasi pandemi dengan banyak protokoler mendorong peserta didik memiliki ketahanan dalam komunikasi digital. Asumsi kemudahan daring bagi mahaisswa dengan begitu perlahan akan semakin menunjukkan hasilnya. Bagi sumber daya pendidik apakah dia guru maupun dosen pastinya mendapatkan sesuatu yang tidak jauh dari apa yang didapat peserta didiknya. Karena bagaimanapun pendidikan memiliki karakteristiknya yang khas yakni berdaya perubah. Sehingga bagaimanapun situasinya sejatinya merupakan tantangan pendidikan untuk mewujudkan konsistensi ontology pendidikan itu sendiri. 


\section{SIMPULAN}

Mengacu kepada standar pengukuran ketahan daring seorang dosen dalam mengemban tugas serta perannya di tengah pandemic. Dosen dilingkungan PGSD-UMC sebagaimana telah kami survey menunjukkan hasil yang masuk dalam kategori memiliki ketahanan dalam pembelajaran daring.

pembelajaran yang tidak lain merupakan tanggungjawab sekaligus kesempatan mengembangkan diri dan mahasiswanya,

mampu

direalaisasikan tanpa terlepas pada indicator pengukurnya. Meski di tengah situasi pandemi seperti sekarang, ruang virtual memberi peluang sebesar-besarnya bagi tumbuh dan berkembangnya kompetensi sumber daya pendidik di lingkungan UMC sekaligus sarana menstimulus peserta didiknya. Sebagaimana hasil penelitian survei ini berasumsi bahwa pendidikan menghendaki pembelajaran yang kompetitif.

\section{DAFTAR PUSTAKA}

Abdul Karim, B. (2020). Pendidikan

Perguruan Tinggi Era 4.0 Dalam

Pandemi Covid-19. Education and Learning Journal 1(2):102. DOI: 10.33096/eljour.v1i2.54

Febiarso Sasongko. (2020).

Tantangan Pembelajaran Secara

Daring.

https://ldikti5.ristekdikti.go.id

Hartono. (2012). Eefektivitas Weblog Dan Facebook Terintegritasi Untuk Pembelajaran Virtual. http://perpustakaan.unitomo.a c.id/repository/1868-5247-1PB.pdf

Ilyasir, F. (2019). Pendidikan

Demokratis Di Era Revolusi 4.0. Jurnal Pembangunan

Pendidikan: Fondasi dan

Aplikasi. Vol 7, No1.

https://journal.uny.ac.id/index.ph p/jppfa/article/view/25998
Isjoni dan Ismail, A. (2008). Modelmodel Pembelajaran Mutakhir. Yogyakarta. Pustaka Pelajar.

Kemdikbud. (2020). https://Imsspada.kemdikbud.g o.id/

Khozanah, Hindun DKK. (2019). Efektifitas Pengelolaan Pembeljaran Myob Accounting Berbasis Weblog di SMKN I Sragen. http://journals.ums.ac.id/index. php/varidika/article/view/1021 9/5280

Morrisan MA, Dkk. (2012). Metode Penelitian Survei. Kencana. Jakarta.

Mas'udi W, Winanti, PS. 2020. Tata Kelola Penanganan Covid-19 Di Indonesia: Kajian Awal. UGM-Press

Sutisno, A. N. (2014). Telaah Filsafat Pendidikan. Deepublish. Yogyakarta. 
Sutisno, A.N. (2016). Menyoal Makna Peran Guru Dalam KBM sebagai Dasar Pedagogi (Tinjauan Filsafat IImu). Proceedings of The International Seminar On Philosophy Of Education. Primary Foundation In Strengthening Pedagogy Development In Indonesia Future Generation. Universitas Pendidikan Indonesia. 2016. Hal: 132-137

Tim Kemenristekdikti. (2017). Buku Panduan Pengisian Survei dan Pembelajaran Daring. Jakarta

Yu-Chung Kuo, Brian R. Belland and Yu-Tung Kuo. (2017). Learning Through Blogging: Students Peprspectives in Collaborative
BlogEnhanced Learning Communities. Educational Technology\&Society, 20 (2), 37-50

Yide Shen, Rong Guo, dkk. (2018). Using Social Media to Improve Student-Instructor Communication in an Online Learning Environment. International Journal of Information and Communication Technology Education. Volume 14. Issue 1. Januari-March. file://C:/Users/USER 1.DES/ AppData/Local/Temp/UsingSocial-Media-to-ImproveStudent-InstructorCommunication-in-an-OnlinefLearning-Environment2017.pdf 